\title{
Queer Bedfellows of Proposition 8: Adopting Social Conservative and Neoliberal Political Rationalities in California's Same- Sex Marriage Fight
}

\begin{abstract}
ALEXA DEGAGNE
University of Alberta, Canada

Abstract On November 4, 2008 California voters passed Proposition 8, and accordingly same-sex marriage was banned under the state constitution. Proposition 8 is now being considered by the Supreme Court. The proposition has sparked national debate about the nature of the relationship between the state and citizens' sexuality and corresponding rights; calling into question the practice of allocating rights and privileges on the basis of sexuality and family form. Proponents of the proposition, who can be classified as predominantly socially conservative, want to maintain the status and privileges of marriage for heterosexuals; arguing that allowing same-sex marriage threatens the legitimacy, sanctity and strength of traditional heterosexual marriage. This article examines the extent to which three Californian pro-samesex marriage organizations (Equality California, Join the Impact, and the Courage Campaign) have challenged and/or appropriated social conservative and neoliberal discourses in their effort to gain access to the rights and privileges that are currently administered through marriage.
\end{abstract}

\section{Introduction}

On November 4, 2008, Californians voted on Proposition 8 which would ban same-sex marriage under the state constitution. With a 52.24\% majority, Proposition 8 passed and, accordingly, formally expanded rights were retracted through instruments of direct democracy (Grodin, 2009). Proposition 8 has sparked national debate about the nature of the relationship between the state and citizens' sexuality and corresponding rights. It calls into question the practice of allocating rights and privileges on the basis of sexuality, sexual conduct and family form.

Opponents of Proposition 8, for the most part members of the mainstream 
gay and lesbian movement, argued that homosexual citizens deserve the same rights as their heterosexual counterparts (No On Proposition 8, OctoberNovember 2008). Both sides agreed that there are many rights and privileges attached to marriage, and mainstream same-sex marriage advocates wanted the equal status and rights that come with marriage, including: employment benefits, adoption rights, access to reproductive technology, immigration and travel rights and protections, parental leave benefits, and health benefits (Josephson, 2005). Proponents of the proposition, who can be classified as predominantly socially conservative, have wanted to maintain the status and privileges of marriage for heterosexuals, arguing that allowing samesex marriage threatens the legitimacy, sanctity and strength of traditional heterosexual marriage (Protect Marriage: Yes on Proposition 8, OctoberNovember 2008).

For both groups marriage is understood, among other things, as a vehicle for social and political inclusion wherein the family is championed as the primary unit of society and marriage as an institution through which the state should allocate certain rights and privileges.

As Angus Cameron states, the boundaries of social exclusion and inclusion occur according to the normal/abnormal binary. He says: "The social exclusion/inclusion debate is an exercise in normative boundary setting - a means of distinguishing between a form of social being characterized by normality, morality, responsibility, independence and competitiveness and a form of social being marked by difference, redundancy, pathology, immorality and obsolescence" (Cameron, 2006, p. 401). Identities, be they racial, gendered or sexual, are categorized and valued as either normal or abnormal. If individuals want to move into a space of inclusion, they have been required to assimilate to a normal, and therefore valued, identity. In liberal regimes, practitioners of identity politics have long stood on the premise of seeking to move from positions of social and political exclusion to positions of inclusion in order to gain the attendant statuses, rights, protections and privileges. Accordingly, minorities and excluded subjects have had to wrestle with whether it is beneficial and productive to acquiesce to their societies' and governments' terms of inclusion (Goodin, 1996; Peace, 2001).

Barriers to social and political inclusion come in the form of government law and policy and institutional regulations and restrictions. In the United States, marriage has historically been one such institution, as inclusion is granted to those who can conform to the idealized heteronormal family, complete with designated normalized gender and sexual identities. The inclusion in the institution of marriage offers state political and economic benefits and protections, social status and legitimacy.

Political rationalities and their discourses have defined the criteria for what is normal and abnormal, legitimate and illegitimate, and therefore define the terms of inclusion and exclusion. I contend that in the contemporary American political landscape, social conservative and neoliberal political rationalities and their discourses have complicated and conditioned the terms of inclusion and exclusion with regard to marriage, ultimately defining the criteria for 
citizens' normal and abnormal, legitimate and illegitimate, acceptable and unacceptable sexual identities and family forms. Thus, when making claims for political and social inclusion, same-sex marriage advocates have had to consider and navigate, embrace or reject neoliberal and social conservative political rationalities.

This article investigates how specific political rationalities and their discourses determine the criteria for social and political inclusion. Specifically, I examine the extent to which Californian gay and lesbian social movement organizations, which were involved in Proposition 8, have adopted, challenged or appropriated social conservative and neoliberal discourses and political rationalities in their effort to gain social and political inclusion through same-sex marriage.

In the first half of the article, I outline my theoretical framework that explores the connections between political rationalities, discourses, social and political inclusion. I consider these concepts in relation to the current preoccupations of American social conservatism, the current neoliberal and social conservative citizenship models, and the political and social goals of the American gay and lesbian movement. In the second half of the article, I examine the websites of three opponents of California's Proposition 8: the Courage Campaign, Join the Impact and Equality California. Language, logic and truths comprise political rationalities and ultimately determine the criteria for social and political inclusion. As such, I will analyze the language, ideas and arguments used on these websites to determine the degree to which these gay and lesbian organizations are challenging or capitulating to the dominant social conservative and neoliberal political rationalities and citizenship models in their attempt to gain social and political inclusion.

\section{Theoretical Framework}

\section{Political Rationalities and their Discourses}

I hold that the criteria for social and political inclusion are determined by political rationality. Elaborating on Foucault's early formulation, Brown (2006) defines "political rationality" accordingly:
A political rationality is not equivalent to an ideology stemming from or masking an economic reality, nor is it merely a spillover effect of the economic on the political or the social. Rather, as Foucault inflected the term, a political rationality is a specific form of normative political reason organizing the political sphere, governance practices, and citizenship. A political rationality governs the sayable, the intelligible, and the truth criteria of these domains. (p. 693-694)

Within a political rationality, certain knowledge and truths are championed, valued and legitimated (Apple, 2000; Fisher, 2006).

According to Foucault, discourse, a means of disseminating a political rationality, is productive. "Discourse is, with respect to the relation of forces, not merely a surface of inscription, but something that brings effects" 
(Foucault, 1997, p. xx). Discourse is not merely the linguistic representation of power relations, but a constitutive element of power relations. Discourse produces and conditions the dynamics, interpretations and reactions within different power relations. Discourse is not external and superfluous to power and knowledge (or "truth") coming together; rather, power and knowledge are joined in discourse (Foucault, 1978; Sedgwick, 2008). Thus, discourse forms, conveys, and perpetuates a political rationality.

Political rationality, constituted of discourses, constructs and conditions dominant governance practices, and determines the boundaries of citizenship and inclusion. There are various political rationalities that define the landscapes of citizenship exclusion and inclusion. The concept of political rationalities has been explored in terms of programs of governance, but I argue that political rationalities also condition understandings and ideas about sexuality and family. Accordingly, I have identified neoliberalism and social conservatism as being dominant (at times intertwined and/or combative) political rationalities that shape contemporary American criteria for inclusion and exclusion in relation to issues of marriage, sexuality and the family. I will define these two rationalities and their sexual politics in this section. I will also define the mainstream gay and lesbian and queer theories and politics that are forced to function with, within or outside the dominant neoliberal and social conservative political rationalities and corresponding sexual citizenship model in order to gain social and political inclusion.

\section{Social Conservative and Neoliberal Political Rationalities and Sexual Citizenship Models}

America's current social conservative movement finds its roots in the New Right and the Religious Right groups that were birthed in the mid-1970s. New Right and Religious Right groups emerged in the 1970s as, among other things, a Christian-based social conservative backlash against the feminist and gay and lesbian movements that had been, respectively, fighting for full citizenship rights for women and homosexual Americans. By 1975, the political and social influence of the gay and lesbian movement was apparent as cities and counties were adopting gay rights ordinances, legal challenges to state sodomy laws were underway, and homosexuality was removed from the American Psychiatric Association's list of mental disorders (Fetner, 2001). In the last three decades, however, there has been a surge of homophobic legislation in the form of state ballot initiatives to ban same-sex marriage (Soule, 2004; Witt \& McCorkle, 1997) and restrictions on adoption by homosexual couples (Stacey \& Biblarz, 2003).

With regard to its political rationality, George Lakoff states that social conservatism is based on several generalized beliefs about human nature and society. Social conservatives believe that humans are naturally selfish and imperfect. Social conservatives argue that religion and tradition should be used to teach individuals to be unselfish, cooperative and loyal members of 
society, and to teach individuals proper moral conduct. Moreover, humans need higher authorities to teach individuals how to act in society, and to regulate or punish individuals who do not conform to so society's rules or morals codes (Lakoff, 1996). Historically, social conservatives have depended on churches, community organizations, families and the government to teach and reinforce moral order and community loyalty.

The family, in particular, is foundational to society, according to social conservatives, because it instills tradition, morality, responsibility, proper gender roles and religious devotion. Brenda Cossman (2005) explains: "Individuals are first and foremost members of communities, united by common morals, values and traditions. Within this vision, the family is the basic unit of society, forging individuals together through its moral authority, instilling children with moral values and traditions" (p. 433). The social conservative ideal family is heterosexual and patriarchal. Social conservatives believe that proper moral families must have a mother and a father who are married (heterosexual), and that the father should be the economic and moral head of the household while the mother assumes a subservient role as the nurturer of their children (patriarchal). This heterosexual and patriarchal model is based partially on tradition that has developed since the industrial revolution and partially on religious doctrine.

Since the 1970s, social conservatives have argued that marriage is simultaneously being abandoned by heterosexuals through divorce, women's economic independence, single-parenthood and multi-generational systems of care (Faludi, 1991; Marecek, 2003), while also being attacked by feminists and denigrated by homosexuals (Duggan \& Kim, 2006). Social conservatives, therefore, embarked on campaigns to both promote the benefits of marriage for heterosexuals and guard marriage from homosexuals (Stacey, 1997). This climate was particularly hostile for gay and lesbian activists as social conservatives were working, as they are today, to not only deny the privileges to homosexuals, but also to fortify heterosexual marriage by amassing a larger population of married heterosexuals. As a result, social conservatives have attempted to defend marriage by fortifying the boundaries of exclusion and by strengthening heterosexual marriage by offering privileges to a growing population of "deserving," "good" and "moral" citizens.

It has also been argued that neoliberalism is the dominant discourse shaping contemporary political rationality and mode of citizenship. Since the end of the Second World War until the 1970s, the relationship between the state and citizens occurred within the ideological parameters of the welfare state (Isin, et al., 2008). Social justice was defined in terms of the economic equality of citizens and the state was responsible for regulating and assuring the redistribution of capital and resources (Brodie, 2008). Although the degree and effectiveness of this redistributive social citizenship has since been criticized by feminists and conservatives alike, the definition of citizenship was expanded under this economic regime. Specifically, the citizen acquired social rights, at least in terms of a minimum standard of living, and the state assumed a new role as supporter of the most destitute citizens (Isin, et al., 
2008).

Neoliberalism dismantled this model by espousing the following tenets: reduced public expenditure, deregulated markets and delegitimization of claims-making. Harder applies Foucault's theory of neoliberalism which stresses self-sufficiency and individualism (Foucault, 2008; Harder, 2009). The individual, not the state, takes on the economic, political and social risks of living. With no welfare safety net, the state has no responsibility toward the individual except to assure that there is a "free" market within which individuals can interact and support themselves (Foucault, 2008). Thus neoliberal citizenship is based on self-reliance and respect for limited state intervention (Brodie, 1994). Hesford (2006) and Brown (2009) argue that in America's neoliberal system, families, in their bourgeoisie form, have replaced other forms of political participation and have become a means for economic survival. The family is presented as an economically stable unit and marriage is promoted accordingly. Political participation and belonging now come in the form of private consumer consumption and economic self-sufficiency. As Hesford (2009) warns, this privatization of citizenship silences citizens and impairs their political engagement.

Both social conservatism and neoliberalism are promoting a particular model of citizenship. Specifically, the concept of sexual citizenship has emerged to explain the relationship between the state and citizens' private sexual lives and "intimacies" (Plummer, 2003). Plummer (2003) defines intimacy accordingly:

Intimacy exists within the doing of sex and love, obviously, but also in the doing of families, marriages, and friendships, in child bearing and child rearing, and in caring for others. In these instances, intimacy is likely to have close links to particular kinds of gender, body projects, and feeling work. Bodies, feelings, identities, relationships, interactions, even communities-all are central elements in doing intimacies. (p. 13)

The benefits of citizenship, attained through movement into inclusive spaces, are doled out according to an individual's public and private conduct. The performance of citizenship becomes connected to the performance of intimacies. Sexuality is seen as a site of power both precious and dangerous that must be protected and/or harnessed in a particular way and to particular ends. There is power in the creation of truth and sexuality becomes immersed in a struggle about who can create the truth about sexuality and then harness its power (Foucault, 1978). Citizenship extends beyond the political arena and very much occurs within individuals' private lives. Under this citizenship model, the criteria for inclusion and belonging change depending on the contemporary needs of the state.

Individuals modify their own behavior according to social norms for fear of punishment, certainly, but also for fear of isolation, demonization, and the denial or loss of privilege. Individuals do resist discourses and truth regimes in their everyday lives, in the banal and in the extreme, subtlety and unknowingly or consciously and overtly. Individuals, and groups of 
individuals are constantly pushing against and testing the boundaries of acceptable behavior. And while there is room for experimentation and evolution, as Foucault argues in Abnormal, there are always clear and untraversable boundaries of what is socially acceptable or in need of reprimand, regulation or ostracization (Foucault, 2003).

Rubin, Warner and Foucault agree that the current understanding of acceptable sexuality is dependent on multiple criteria which are predominantly divided according to normality and abnormality (Foucault 1978; Rubin 1993; Warner 1999). For Rubin, the binary criteria are ranked according to the configuration of partners (whether same-sex, multi-generational), number of participants (whether in pairs or otherwise), and according to location (whether public or private). Rubin summarizes that monogamous heterosexuality is at the top of the hierarchy where it redeems all the associated privileges and, predictably, homosexuality, particularly non-monogamous homosexuality, is at the bottom and is punished accordingly (Rubin, 1993).

Because the criteria for acceptable sexuality are based on a normal/ abnormal binary, scholars have recognized that the content of the binaries are not unchanging. Rubin states that heterosexuality can be good/normal or bad/ abnormal but is rarely the latter, while homosexuality has been predominantly bad/abnormal until recently (Rubin, 1993). As will be discussed in more detail in the next section, Warner argues: “'Queer' gets a critical edge by defining itself against the normal rather than heterosexuality" (Warner, 1993, p. xxvi). Queer theory scholars therefore question the validity of judging sexuality according to normalcy in the first place by constantly pushing back against the ever- changing criteria of normal privileged sexuality.

\title{
3. Possibilities for Resistance and Transgression
}

Robert Goodin (1996) has critiqued “social exclusion” scholarship, arguing:

\begin{abstract}
The true source of our anxieties, I shall argue, lies not in the practice of exclusion but in that of inclusion. The problem is not - not just, not even principally - that too many people, or the wrong people, have been "left out"; nor is the proper remedy more "inclusive" communities. Instead, I argue, the problem of exclusion is that there is an inclusive community, be its catchment broad or narrow. And if that is the problem, then the solution is not to make our communities more inclusive but rather to change their nature-making them at one and the same time both less exclusive and less inclusive. (p. 344)
\end{abstract}

According to Goodin, oppressed or excluded groups should neither seek to expand the boundaries of inclusion to accept their people nor attempt to change themselves in order to gain acceptance. Pursuing either political strategy only reinforces the legitimacy of the division between inclusions and exclusions. Likewise, Young argues that those involved in identity politics should actually question and challenge the very notion, worth and effects of exclusionary and inclusionary social and political boundaries (Young, 2002). 
Challenges to the inclusions and exclusions of sexual citizenship models are simultaneously moments of transgression and assimilation. According to Foucault, resistance (or transgression) occurs when subjects question, challenge and resist their socially constructed identity (Foucault, 1978). Pickett (1996) explains Foucault's theory of resistance and transgression:

Transgression is now conceived as an implicit affirmation of difference ... The various rules, limits, and norms history has placed upon us, which are often seen as natural, are the sources of exclusion, marginalization, and the resulting solidification of identity for those who "confine their neighbors." Through transgression it is possible to undermine these limits, although new ones will always arise. This affirmation of difference is thus a permanent agonistic stance. (p. 450)

As Foucault, and later Butler argue, expanding the criteria and boundaries of inclusion merely redefines the populations that are excluded (Butler, 2002; Foucault, 1978). Butler (2002) states:

It is important to mark how the field of intelligible and speakable sexuality is circumscribed so that we can see how options outside of marriage are becoming foreclosed as unthinkable, and how the terms of thinkability are enforced by the narrow debates over who and what will be included in the norm. (p. 18)

Subjects must thus push back against their negatively constituted identities while remaining conscious of, and attempting to avoid, the ostracization of others in the process.

In the case of same-sex marriage, it appears that some gay and lesbian individuals and couples are willing, in fact insisting, that they can and will assimilate to the criteria of state belonging through their kinship structure, roles and responsibilities in order to gain social and political rights and privileges. Instead of challenging the fact that these rights and privileges are allocated according to state sanctioned kinship formation, some, definitely not all, gay and lesbian activists have decided to simply ask to be included in the institution of marriage (Butler, 2002). Accordingly, Polikoff argues that some same-sex marriage advocates are positioning themselves on the "wrong side of the culture war over acceptable family structures," as they engage in debates about privileging particular family forms, thus emulating the social conservative's hierarchal valuing of sexualities and family forms (Polikoff, 2008).

Some radical queer scholars, such as Dean Spade and Craig Willse, Nancy Polikoff, Judith Butler, Mark Blasius and Michael Warner, hold that any state legitimization of any relationships will always exclude segments of the population who are not involved in recognizable relationships (Blasius, 1994; Butler, 2002; Polikoff, 2008; Spade and Willse, 2010; Warner, 1993). These queer activists and scholars argue that this push for same-sex marriage is a capitulation to an institution that has historically been patriarchal, racist, and has ostracized and punished non-heterosexual citizens including homosexual, polyamorous, polygamous, single, transgender and gender- 
non-conformist people (Bell \& Binnie, 2000; Butler, 2002; Warner. 1999). With the expansion of marriage to homosexuals, other deviants are free to be heterosexual or homosexual, but never non-monogamous, polyamorous or polygamous. Thus, by asking for marriage rights, same-sex couples are effectively redrawing the lines of exclusion and abandoning other sexually "deviant" individuals.

Cooper goes on to explain that when gay and lesbian advocates ask to be included into institutions, such as marriage or the military, in order to gain rights and equalities, they are actually causing inequalities in resources, entitlements, freedoms, authority and discursive/cultural recognition (Cooper, 2002). In choosing to marry, and enter the institution, gay and lesbian individuals will have an interest in maintaining the strength, meaning, privileges, and protections of the institution and its participants (Lehr, 1999). And the gay and lesbian fight for same-sex marriage assumes an interest in maintaining the legitimacy of the institution, and the boundaries between rights-bearing and rights-denied individuals, both of whom are still under the regulation of the state.

Accordingly, some queer theorists resist the normalizing and exclusionary nature of this current sexual citizenship model by arguing that social and political rights and privileges should not be attached to family form, sexuality and sexual conduct. Otherwise, social justice, in terms of voices heard and needs met, is shallow, as large segments of the population are denied political representation, social rights and economic protections. Social and political inclusion is reserved for the few who lead morally acceptable gendered, sexual and familial lives.

Two main political rationalities have been presented, each with a different understanding of the nature and boundaries of belonging through sexual citizenship and marriage. First, social conservatives argue that marriage is necessarily privileging and should be reserved for heterosexual couples, as they are the most natural, moral and traditional family form. Further, heterosexual couples are needed to reproduce desired and 'good' future citizens (Cossman, 2005). Second, neoliberals hold that economic dependence and risk should be privatized and preferably reinforced through the permanence of a marriage (or marriage-like) contract. Still, neoliberals are hesitant to extend marriagelike rights to a broader population as it will require private corporations and the government to provide health and other employment benefits to more citizens. In both cases, inclusion is reserved for a select portion of the population.

In the presence of these political rationalities, mainstream gay and lesbian marriage advocates accept marriage as an acceptable exclusionary space and a means to gain rights and protections. As is seen in the next section, some gay and lesbian activists have even appealed to social conservative and neoliberal political rationalities by arguing that marriage will enable homosexuals to fulfill their responsibilities to society as normal and selfsufficient consumers, producers and reproducers (Bell \& Binnie, 2000). 


\section{Case Study \\ Three Gay and Lesbian Organizations of Proposition 8}

I use the recent vote and passage of Proposition 8 in California as a case study to analyze the degree to which Californian gay and lesbian activists are subscribing to social conservative and neoliberal political rationalities pertaining to sexual citizenship. The initiation and passage of Proposition 8 actually retracted social inclusion as gay and lesbian Californians were granted marriage rights by the State Supreme Court in May 2008 only to have them taken away in November 2008 via popular vote.

As stated, there are several economic and social rights and privileges that are allocated through marriage, including access to partner employment and health benefits, welfare bonuses, medical information and decision rights, adoption and second parent rights, parental leave benefits, and immigration and travel privileges (Josephson, 2005).

Before, during, and after the passage of Proposition 8, various gay and lesbian organizations emerged in support of the "No" campaign. I have identified three of the most prominent groups on this side of the fight including: Equality California, Join the Impact, and the Courage Campaign. The three organizations are California based, focusing predominantly on issues of concern for the gay and lesbian citizens and communities in the state. Equality California was founded in 1998 to fight for legal protections and rights on a state and national level for gay, lesbian, bisexual and transgender Californians. Equality California touts itself as the leading organization in the 'No on Proposition 8' battle as it raised 14 million dollars for the campaign, 11 million dollars more than any other organization (Equality California, 2009).

Join the Impact was created in the days following the passage of Proposition 8 in November 2008. Join the Impact defines itself as a grassroots organization pursuing the goal of full equality for gay and lesbian citizens through education, outreach and protest. Among their accomplishments, Join the Impact coordinated protests against Proposition 8, and similar propositions in other states, in three hundred cities inside and outside the United States on November 15, 2008. Although Join the Impact seeks to challenge its opponents, the founders of the organization are adamant that they do not want to demonize, blame or attack opponents to same-sex marriage; doing so will only close lines of communication and extinguish any possibility for understanding and compromise (Join the Impact, 2009). As can already be seen, these two organizations are interested in legal protections, formal equality and rights for gay and lesbian Californians. Further, both are interested in dialoguing and compromising with oppositional and undecided voters.

The other main group, the Courage Campaign, argues that extending marriage rights to homosexuals will not compromise the sacred, moral, and healthy nature of marriage. The Courage Campaign is an online organization that works to connect left- leaning grassroots organizations and individuals 
around issues including education policy, health care, taxation, and most relevant to this study, gay and lesbian rights and protections. Courage Campaign is comprised of over 700, 000 members. These members are mobilized under the "Courage Campaign Equality Program" which organizes volunteers in each of the state's counties and sends volunteers to go doorknocking in order to speak one-on-one to Californians in an attempt to open dialogue, put a "human face" to the same-sex marriage struggle, and convince opponents and undecided voters that Proposition 8 seeks to deny "normal," "average" citizens access to the rights currently associated with marriage (Courage Campaign, 2009a).

For this project I surveyed the websites of these three organizations, paying particular attention to their mission statements, press releases, daily or weekly updates, blog entries (of the founders and/or leaders of the organizations), emails, and published reports, papers or documents. For two of the websites, I was able to recover information dating as far back as May 2008 when the California Supreme Court ruled that restricting marriage to heterosexual couples was unconstitutional in Re Marriage Cases (Supreme Court of California, 2008). The third organization, Join the Impact, was created in November 2008 and I was able to access their archives dating back to their founding.

This research unearthed two main ways in which these organizations have adopted, challenged, or appropriated social conservative and neoliberal discourses in their attempts to gain equal rights through same-sex marriage. First, these organizations promote the "normalcy" of homosexuality in order to fit into the social conservative criteria of acceptable sexuality. Second, they claim that heterosexual and homosexual couples share common form and function as they practice monogamy, child bearing and economic selfsufficiency. Ultimately, these groups have made a case for why gay and lesbian Californians should be granted marriage rights, without questioning why rights are allocated through private sexual relationships. Each of these themes will now be addressed in turn.

\section{Normalizing Homosexuality}

Three of the Californian gay and lesbian organizations, the Courage Campaign, Join the Impact and Equality California, are not practicing Foucault's theory of resistance (Foucault, 1978). These groups are attempting to deny social conservative discourses that constitute homosexuals as deviant and abnormal. But Equality California in particular is trying to normalize certain homosexuals by demonizing others. Equality California calls the deviants "San Francisco Gays," referring to flamboyant, leather-wearing, sadomasochistic, promiscuous homosexuals. Thus, these groups are trying to gain social acceptance and inclusion, not by showing that homosexuality is not scary or monstrous, but by arguing that specific homosexuals are not a threat. These groups are denying their negatively constituted identity by 
negatively constituting and excluding others.

As mentioned, the Courage Campaign's primary form of protest and mobilization against Proposition 8 was to dispatch volunteers into their communities to knock on their neighbours' doors and engage them in conversation about issues, concerns, truths and lies surrounding same-sex marriage. The Courage Campaign used this strategy of resistance, they explain, in order to demonstrate the "human face" of homosexuals and homosexuality. They hoped that in doing so opponents and undecided voters would realize that homosexuals are not abnormal or scary but rather that they are neighbours, co-workers, and fellow citizens who want to protect and provide for their children and partners (Courage Campaign, 2009a).

Equality California promotes the same tactic, focusing on the stories of the 18,000 same-sex couples that were married before the passage of Proposition 8. Equality California states:

We also will ensure that Californians really get to know the 18,000 samesex couples whose marriages are recognized by the state, as well as their family members, friends and loved ones. The truth of their lives belies the misconceptions our opponents propagate. As these families simply live their lives, they will demonstrate to all Californians that same-sex couples want to be civilly married because they have the same hopes, dreams, concerns and sense of responsibility as any other family. (Equality California, 2009)

Rather explicitly, Equality California is seeking to demonstrate that the homosexual couples that were married before Proposition 8 are normal, healthy and harmless. These couples do not wish to dismantle the institution of marriage from the inside, rather they respect the institution and support the accompanying values of personal responsibility and commitment.

Join the Impact also initiated a similar campaign as they asked their followers to engage ten people, be they family, friends, acquaintances or strangers, in conversation about the need for a same-sex marriage law and the implications of its denial. Join the Impact argued that initiating these conversations would be effective as the conversation would be brought down to a personal and intimate level, ultimately detaching individual homosexuals from the stereotypical and demonized characterization that is promoted by religious and social conservative groups (Join the Impact, 2008, November 15). It can be argued that homosexuals are humanized through this individualization because homosexuals become defined by more than their "deviant" and "unhealthy" sexuality. In this instance, homosexuals become family members, parents, workers, consumers, religious followers and tax- paying citizens, despite their sexuality. Admittedly, this is a very thin line to tread. Gay conservatives such as Andrew Sullivan and Bruce Bawer claim that the erasure of sexuality is a necessary and positive outcome of the legalization of same-sex marriage. The institution of marriage, they argue, will serve to civilize and regulate homosexuals according to the heterosexual values of monogamy, life-long commitment, private dependence and economic self-sufficiency (Bell \& Binnie, 2000; Josephson, 2005). Thus, 
through the structure of marriage, homosexuals can and will assume the same civil responsibilities of their heterosexual counterparts and sexuality will become a matter of private concern. Yet, as Cossman contends, this privatization and silencing of sexuality obscures the ever-present relationship between sexuality and social justice in terms of economic opportunities and prosperity, political rights and equality, and cultural discrimination (Cossman, 2005).

This attempt to demonstrate the "normality" of homosexuality and homosexuals is accompanied by a subtle call to distance the same-sex marriage movement from extreme, overt and scandalous expressions of homosexuality, represented by the "San Francisco homosexuals." Mainstream same-sex marriage advocates define the San Francisco homosexuals in the same fashion that social and religious conservatives do, as promiscuous, drugtaking, parade performing, leather wearing, sadomasochistic, irresponsible, childish, selfish and diseased individuals. In their document, "Winning Marriage Back: Report and Analysis," Equality California argues:

We also make sure there are stories in the local newspaper and on television about couples who live locally who are married, or who want to marry. Voters see that marriage equality is not just those gays in San Francisco, but the couple that lives down the street in Bakersfield, or the daughter of their close friends, or the parents of their kid's school friend. (Equality California, 2009, p. 15)

Join the Impact similarly pleads:

We beg to be given a right that requires responsibility and commitment, yet we, as one strong community, have not proven to this nation that we deserve to be taken seriously! The gay pride parade has become a great party, but it has lost the memory of Stonewall and therefore given the nation another reason to cast us aside as irresponsible. It's time we come together for debate, for public recognition, and for LOVE! (Join the Impact, 2008, November 10)

These same-sex marriage advocates are finding a common enemy with religious and social conservatives: the abnormal, un-assimilable homosexual. As Foucault and Butler argue, these populations are portrayed as being un-assimilable and are thus delegitimized (Butler, 2002; Foucault, 2003). Mainstream gay activists are essentially pushing the San Francisco gays outside of the inclusive realm of the normal, legitimate and acceptable in order to bring the taxpaying, monogamous, childrearing homosexuals into the realm of legitimacy and privilege. As Fraser argues, injustice occurs when a particular group of citizens is not permitted to participate in the political process or have equal access to economic and social benefits (Fraser, 2005). Instead of questioning the logic of inclusions and exclusions, the strategies of these Californian gay and lesbian organizations are enabling injustice to occur against citizens who cannot or will not marry. 


\section{The Form and Function of Same-Sex Marriage}

In tandem with their strategies of proving that homosexuals and homosexuality are non-threatening and normal, Join the Impact and the Courage Campaign have also tried to demonstrate that homosexual couples are identical with heterosexual couples in function if not in form as well. Co-founder of Join the Impact, Nik Maciejewski argues:

In the movement for LGBTQ rights, specifically that of legal recognition of same sex relationships, activists and others place heavy emphasis on "marriage" being the only possible title to achieve full equality. Equality can't exist until LGBTQ and straight people alike fill out the exact same form for the legal binding of two people. (Join the Impact, 2009, May 28)

Maciejewski believes that homosexual couples' equality is dependent on their replication of the "exact same form" of married heterosexual relationships. Similarly, Amy Balliett, co-founder of Join the Impact, argues that homosexual couples are similar to heterosexual couples in form as they are comprised of two parents with children and possibly extended family dependents. Further, homosexual couples value and engage in monogamous, consensual, life-long relationships. The only difference is, of course, the gender of the two parents (Join the Impact, 2009, January 29). The contract remains between two adults and the state: the state needs only modify the gender criteria for belonging.

To prove they are worthy of social inclusion, some same-sex marriage activists present homosexual couples as similar to heterosexuals in every valued category except for their sexuality (Duggan and Kim, 2006). Join the Impact, Equality California and the Courage Campaign are more than willing to prove that homosexuals can and do fulfill the neoliberal criteria for the functions and responsibilities of marriage including the bearing and rearing of children, care for dependents, economic self-sufficiency, and augmented and constant consumer consumption (Join the Impact, 2009, January 29; Equality California, 2009; Courage Campaign, 2009a).

Organizations on both sides of the Proposition 8 debate launched video campaigns that were released on their respective websites and circulated through YouTube and the other social media outlets. Most pertinently, the Courage Campaign created two video series in support of the same-sex marriage effort in California: "13 Love Stories," "Fidelity: Don't Divorce Us" (Courage Campaign, 2009b). The series "13 Love Stories" is comprised of documentaries on the love stories of 13 non-heterosexual couples. The couples tell the story of how they met, why they love each other, how their families are structured and why they want the right to marry (Courage Campaign, 2009b). These couples are presented in their homes, often surrounded by their children. There is no denying the attempt to create affect through these videos. The message presented is that these couples' families are as normal and their love as sacred as those of heterosexuals.

The second video series, "Fidelity: Don't Divorce Us," was created by Courage Campaign but is promoted by Join the Impact as well. "Fidelity" is 
a collection of pictures of some of the 18,000 couples and their families and friends who were married in California before Proposition 8. The couples and their families are photographed holding signs saying "Please Don't Divorce Us," "Please Don't Divorce Our Friends and Family," "Please Don't Divorce my Moms," "Don't Divorce Love" and so on. In addition, pictures are presented featuring the marriage ceremonies of gay couples. Many of the marriage ceremonies mimic traditional heterosexual marriages. Both Christian and Jewish traditions are showcased. As with "13 Love Stories," emphasis is placed on affect as couples are shown with their children and extended families. Finally, some of the pictures in the video cite the longevity of relationships as proof of their legitimacy. In some cases, captions read, for example, "been together for 18 years, married July 07, 2008" (Courage Campaign, 2009b). Thus, these videos present Californian gay couples as loving, monogamous, two-parent, child-bearing, and religious, propagating the way in which gay couples can assume the form of normal marriages.

With emphasis placed on the economic benefits of same-sex marriage for the families involved, the state and business, these same-sex marriage advocates also argue that same-sex couples perform the necessary functions of marriage as required by neoliberal and social conservative ideologies. As stated, Johnson et al. claim that neoliberals and social conservatives share the belief that the family becomes the default financial support as individuals live, consume, and procreate as family units (Johnson, et al., 2005). Social conservatives promote this arrangement as it assures the propagation of a gendered family form wherein mothers are not supported by the state in child bearing or rearing and thus must depend on their husbands who assume financial responsibility. Neoliberals likewise propagate familial dependence because it assures the privatization of economic dependence, taking onus off the state (Isin, et al., 2008).

Employing this neoliberal and social conservative discourse, Join the Impact, of the three organizations studied, made the most references to the economic benefits of same-sex marriage. A co-founder of Join the Impact has argued that homosexuals contribute to the economy as taxpayers and consumers and deserve state protections allocated to their heterosexual counterparts. As stated: "We are taxpaying citizens who contribute to this economy. We deserve legal protections from our government and marriage provides $10,000+$ legal protections that are not awarded to our families!" (Join the Impact, 2008, November 14). This comment is referencing the "December 10, 2008: Day Without a Gay" campaign, promoted by Join the Impact, calling homosexuals to take the day off work and avoid consuming for a day. Join the Impact argued that this boycott would demonstrate the economic power of the gay community across the United States. Ultimately, Join the Impact is drawing a clear connection between the economic value of homosexual citizens and the need for their inclusion in the institution of marriage. In these campaigns, they have not questioned the privatization of economic dependence or the social conservative and neoliberal justifications for rewarding citizens based on their sexual, familial and intimate decisions. 


\section{Conclusion}

It has been shown that the three 'No On Proposition 8' organizations studied here have adopted certain elements of social conservative and neoliberal political rationalities and their discourses in order to gain social and political inclusion through same-sex marriage. These organizations have tried to prove that homosexuality is normal and that the homosexual family is economically and socially beneficial for society.

Practitioners of identity group politics have focused on moving from spaces of exclusion to spaces of inclusion. When trying to move to spaces of inclusion, however, identity groups risk essentializing the voices or perspectives of the members of the group. This essentialization occurs as there is a tendency for excluded groups to assimilate to criteria of inclusion in order to gain acceptance. Those who cannot easily assimilate are ignored, or worse yet, actively silenced by their supposed allies. The only excluded voices that are heard are of those members that can most easily conform to the criteria for inclusion. In the fight for same-sex marriage, these easily assimilable members are predominantly White, affluent men. Therefore, while identity groups are usually established to protect the needs and rights of minorities, they can also serve to further marginalize, silence and therefore deny social justice to members of their groups who cannot or will not assimilate in order to move into the space of inclusion.

The American gay and lesbian movement is not a monolithic entity wholly concerned with attaining same-sex marriage rights. Despite the fact that popular media and discourse have focused on the gay and lesbian citizens and political organizations that are attempting to gain social and political inclusion through same-sex marriage, there is a substantial and vocal contingent that wants and needs to fundamentally challenge the political rationality of granting social inclusion, including allocating rights and status, through state-sanctioned and regulated intimate relationships.

\section{References}

Apple, M. (2000). Official knowledge: Democratic education in a conservative age. New York: Routledge.

Bawer, B. (1994). A place at the table: the gay individual in American society. New York: Simon \& Schuster.

Bell, D., \& Binnie, J. (2000). Sexing citizenship. In D. Bell \& J. Binnie (Eds.), The sexual citizen: Queer politics and beyond (pp 1-34). Cambridge: Polity Press.

Bernstein, M. (2003). Nothing ventured, nothing gained? Conceptualizing social movement "success" in the lesbian and gay movement. Sociological Perspectives, 46(3), 353-379.

Bernstein, M. (1997). Celebration and suppression: The strategic uses of identity by the lesbian and gay movement. American Journal of Sociology, 103, 531-565.

Blasius, M. (1994). Gay and lesbian politics. Philadelphia: Temple University Press.

Brodie, J. (2008). The social in social citizenship. In E. Isin (Ed.), Recasting the social in citizenship (pp 22-50). Toronto: University of Toronto Press.

Brodie, J. (1994). Politics on the boundaries: Restructuring and the Canadian women's movement, Eighth Annual Robarts Lecture. Toronto: York University.

Brown, W. (2006). American nightmare: Neoliberalism, neoconservatism and de-democratization. 
Political Theory, 34(6), 690-714.

Butler, J. (2002). Is kinship always already heterosexual? Differences: A Journal of Feminist Cultural Studies, 15(1), 14-40.

Cameron, A. (2006). Geographies of welfare and exclusion: social inclusion and exception. Progress in Human Geography, 30(3), 396-404.

Cooper, D. (2002). Imagining the place of the state: Where governance and social power meet. In D. Richardson \& S. Seidman (Eds.), Handbook of lesbian and gay studies. London: Sage.

Cossman, B. (2005). Contesting conservatisms, family feuds and the privatization of dependency. Journal of Gender, Social Policy \& the Law, 13(3), 415-510.

Courage Campaign. 2009a. Equality program. Retrieved from http://www.couragecampaign. org/page/content/aboutus/

Courage Campaign. 2009b. Videos. Retreived from http://www.couragecampaign.org/video

Duggan, L., \& Kim, R. (2006). Beyond gay marriage. In L. Duggan \& N. D. Hunter (Eds.), Sex sars: Sexual dissent and political culture (pp 231-238). New York: Routledge.

Equality California. 2009. Winning marriage back: Report and analysis. Retrieved from http:// www.eqca.org/site/pp.asp?c=kuLRJ9MRKrH\&b=4025493.

Faludi, S. (1991). Backlash: The undeclared war against American women. New York: Anchor Books.

Fetner, T. (2001). Working Anita Bryant: The impact of christian anti-gay activism on lesbian and gay movement claims, Social Problems, 48(3), 411-428.

Fisher, F. (2006). Participatory governance and deliberative empowerment, The American Review of Public Administration, 36 (1), 19-40.

Foucault, M. (2008). The birth of biopolitics: Lectures at the College de France

1978-1979. New York: Picador.

Foucault, M. (2003). Abnormal: Lectures at the College De France. London: Palgrave Macmillan.

Foucault, M. (1978). The history of sexuality: An introduction. New York: Vintage .

Fraser, N. (2005). Reframing justice in a globalizing world. New Left Review, 36, 69-88.

Goodin, R.E. (1996). Inclusion and exclusion. European Journal of Sociology, 37, 343-371.

Grodin, J. R. (2009). On amending and revising the constitution: the issues behind the challenge to Proposition 8, The California Journal of Politics \& Policy, 1(1), 1-4.

Harder, L. (2009). The state and the friendships of the nation: The case of nonconjugal relationships in the United States and Canada. Signs: Journal of Women in Culture and Society, 34(3), 633-658.

Hesford, V. (2009). The politics of love: Women's liberation and feeling differently.

Feminist Theory, 10(1), 5-33.

Isin, E. F., Brodie, J., Juteau, D., \& Stasiulis, D. (2008). Recasting the social in citizenship. In E. F. Isin (Ed.) Recasting the social in citizenship (pp 3-19). Toronto: University of Toronto Press.

Johnson, C.M., Duerst-Lahti, G., \& Norton, N.H. (2007). Creating gender: The sexual politics of welfare policy. London: Lynne Rienner Publishers.

Join the Impact. (2009). Mission Statement. http://jointheimpact.com/about-us/.

Join the Impact. (2009). May 28. http://jointheimpact.com/2009/05/.

Join the Impact. (2009). January 29. http://jointheimpact.com/2009/01/.

Join the Impact. (2008). November 15. http://jointheimpact.com/2008/11/who-we-were-thenwho-we-are-now-part-2/\#more-91.

Join the Impact. (2008) November 14. http://jointheimpact.com/2008/11/what-happensnext/\#more-57.

Join the Impact. (2008). November 10. http://jointheimpact.com/2008/11/prop-8-protest-a-callto-the-lgbtq-community-friends-family/\#more-11.

Josephson, J. (2005). Citizenship, same-sex marriage, and feminist critique of marriage. Perspectives on Politics, 3(2), 269-284.

Lakoff, G. (1996). Moral politics. Chicago: The University of Chicago Press.

Lehr, V. (1999). Queer family values: Debunking the myth of the nuclear family. Philadelphia: Temple University Press.

California Supreme Court overturns gay marriage ban. (2008, May 16). Los Angeles Times. Retrieved from http://www.latimes.com/news/local/la-me-gaymarriage 162008may16,0,6182317.story. 
Marecek, J. (2003). Mad housewives, double shifts, mommy tracks and other invented realities. Feminism \& Psychology, 13(2), 259-264.

Peace, R. (2001). Social exclusion: A concept in need of definition? Social Policy Journal of New Zealand, 16, 17-36.

Pickett, B. L. (1996). Foucault and the politics of resistance. Polity, 28(4), 445-466.

Plummer, K. (2003). Intimate citizenship: Private decisions and public dialogues. London: University of Washington Press.

Polikoff, N. (2008). Beyond gay (straight) marriage: Valuing all families under the law. Boston: Beacon Press.

ProtectMarriage.com. (2008). Yes on Proposition 8. October-November. Retrieved from http:// protectmarriage.com/.

Sedgwick, E. K. (2008). Epistemology of the closet. Berkley: University of

California Press.

Soule, S. A. (2004). Going to the chapel? Same-sex marriage bans in the United States, 19732000. Social Problems, 51(4), 453-477.

Spade, D., \& Willse, C. (2010). I still think marriage is the wrong goal. In Against Equality: Queer Challenges to the Politics of Inclusion. Retrieved from http://www.againstequality.org/

Stacey, J., \& Biblarz, T. J. (2003). (How) Does the sexual orientation of parents matter? In C. Burack \& J. L. Josephson (Eds.), Fundamental differences: Feminists talk back to social conservatives (pp 27-64). Lanham, Maryland: Rowman and Littlefield Publishers Inc.

Stacey, J. (1997). In the name of the family: Rethinking family values in the postmodern age. Boston: Beacon Press.

Sullivan, A. (1997). Same-sex marriage: Pro and con. New York: Vintage.

Supreme Court of California. (2008). Re Marriage Cases. 43 Cal. 4th 757.

Warner, M. (1999). The trouble with normal: Sex, politics, and the ethics of queer life. Cambridge: Harvard University Press.

Warner, M. (1993). Fear of a queer planet: Queer politics and social theory. Minneapolis: University of Minnesota Press.

Witt, S. L., \& McCorkle, S. (1997). Anti-gay rights: Assessing voter initiatives. Westport, CT: Praeger.

Young, I. M. (2002). Inclusion and democracy. Oxford: Oxford University Press.

Warner, M. (1990). Justice and the politics of difference. Princeton: Princeton University Press. 